\title{
Formation of dunite xenoliths in kimberlites and ailikites; petrographic and mineral compositions from a deformed xenolith in the Majuagaa kimberlite dike, Greenland
}

\author{
Nicholas Arndt ${ }^{1}$, Carole Cordier ${ }^{1}$, Troels Nielsen ${ }^{2}$, Valentina Batanova ${ }^{1}$, Anne-Marie Boullier ${ }^{1}$, \\ Igor Ashchepkov ${ }^{3}$
}

\begin{abstract}
1- ISTerre, Univ.Grenoble Alpes, F-38400 Grenoble,France; nicholas.arndt@univ-grenoble-alpes.fr; 2 GEUS, Øster Voldgade 10,DK-1350 Copenhagen, Denmark; tfn@geus.dk; 3 - Institute of Geology and Mineralogy SD RAS, Koptyug ave 3, Novosibirsk, Russian Federation; igor.ashchepkov@igm.nsc.ru
\end{abstract}

\section{Metasomatism accompanying deformation produces dunite}

Kimberlites carry a dense cargo of olivine. Although normally referred to as "macrocrysts", much of this olivine is present in the form of intact or disaggregated multi-grain xenoliths of dunite. Within individual xenoliths, compositions are very constant, but the population as a whole displays a large variation in Fo content accompanied by lesser variation in $\mathrm{Ni}$ and other minor elements. The compositions of dunite xenoliths in kimberlites differ from those of normal mantle peridotites because, in the latter, a decline in Fo content is normally accompanied by an increase in the abundance of opx, cpx and an Al-phase. We propose that the dunite xenoliths in kimberlites result from interaction between mantle peridotite and $\mathrm{CO} 2$-rich fluid from the asthenosphere, a process that removed silicate minerals other than olivine produced a silica-bearing carbonate melt (bonafide kimberlite) or CO2-rich silicate melt (ailikites).

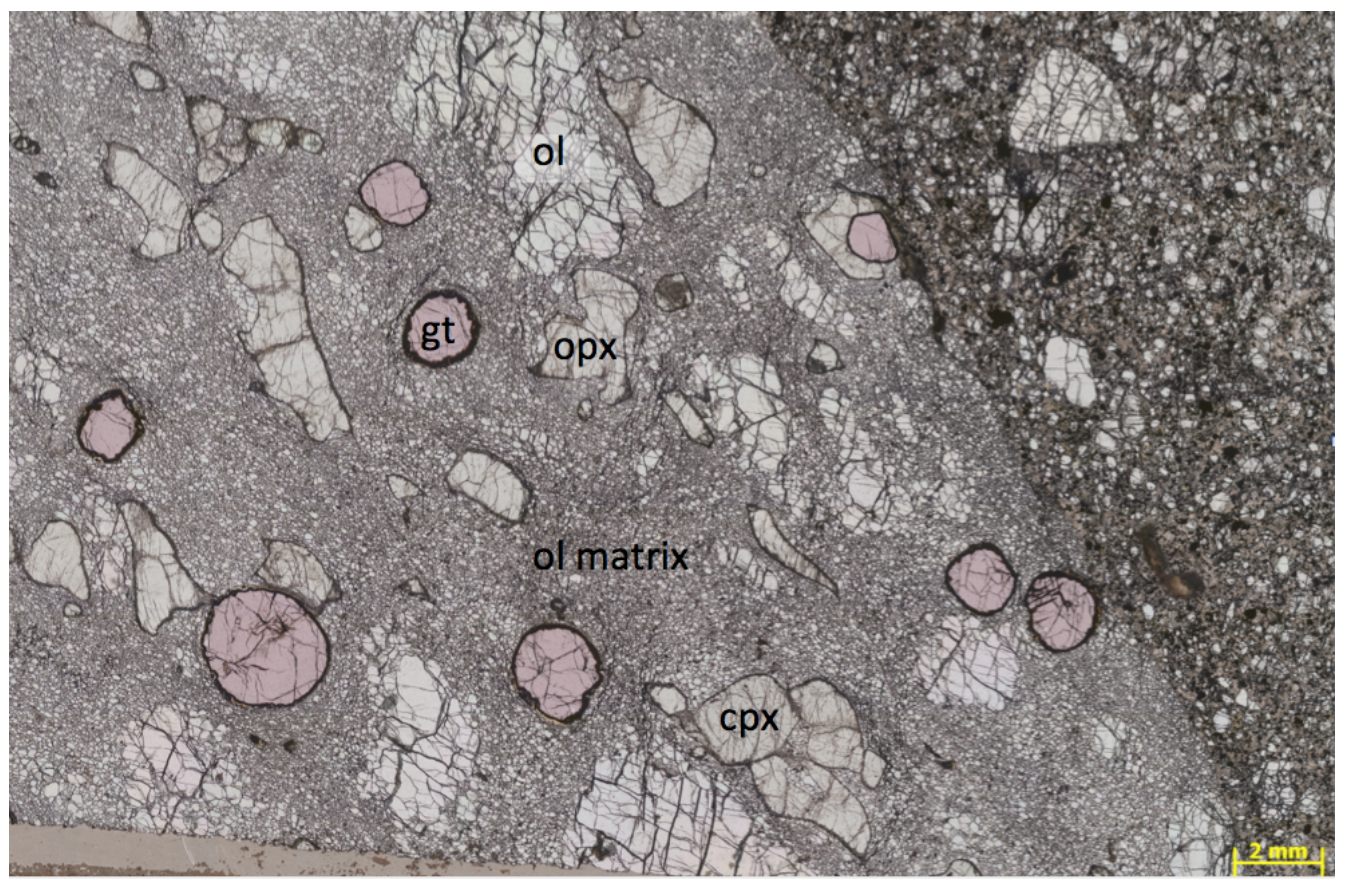

Figure 1: Image of a garnet-lherzolite xenolith in sample 491719, a kimberlite from the Maniitsoq region, in southern West Greenland.

\section{PT conditions}

A garnet-lherzolite xenolith in a kimberlite from the Maniitsoq region, in southern West Greenland, catches the process in the act. The xenolith is strongly deformed and olivine (85\%) has been transformed into large porphyroclastic relicts $(1-5 \mathrm{~mm})$ which lie in a mosaic of much smaller olivine crystals (50-200 microns). Garnets (6\%) are isolated almost spherical; orthopyroxene (8\%) and rare 
clinopyroxene (1\%) are blade-shaped with common embayments. The matrix consists entirely of olivine and has a dunitic composition.

Electron microprobe analyses in the studied sample reveal that porphyroclastic and matrix olivine has the same composition $(\mathrm{Fo}=91.3 \pm 0.03, \mathrm{n}=67)$, a composition in equilibrium with opx $(\mathrm{Mg} \#=92.3 \pm$ $0.001, \mathrm{n}=16)$ and the other minerals. Geothermometry and geobarometry using all four phases defines the PT conditions between these phases: $\mathrm{T}=1221-1281^{\circ} \mathrm{C}, \mathrm{P}=53-60 \mathrm{kbar}$. These conditions correspond to those in the lower part of the lithosphere, with temperatures slightly above a normal craton geotherm $(43 \mathrm{mw} / \mathrm{m} 2)$. This shows that the digestion of orthopyroxene occurred within the mantle rather than during the transport of the xenolith in the kimberlite melt en route to the surface.

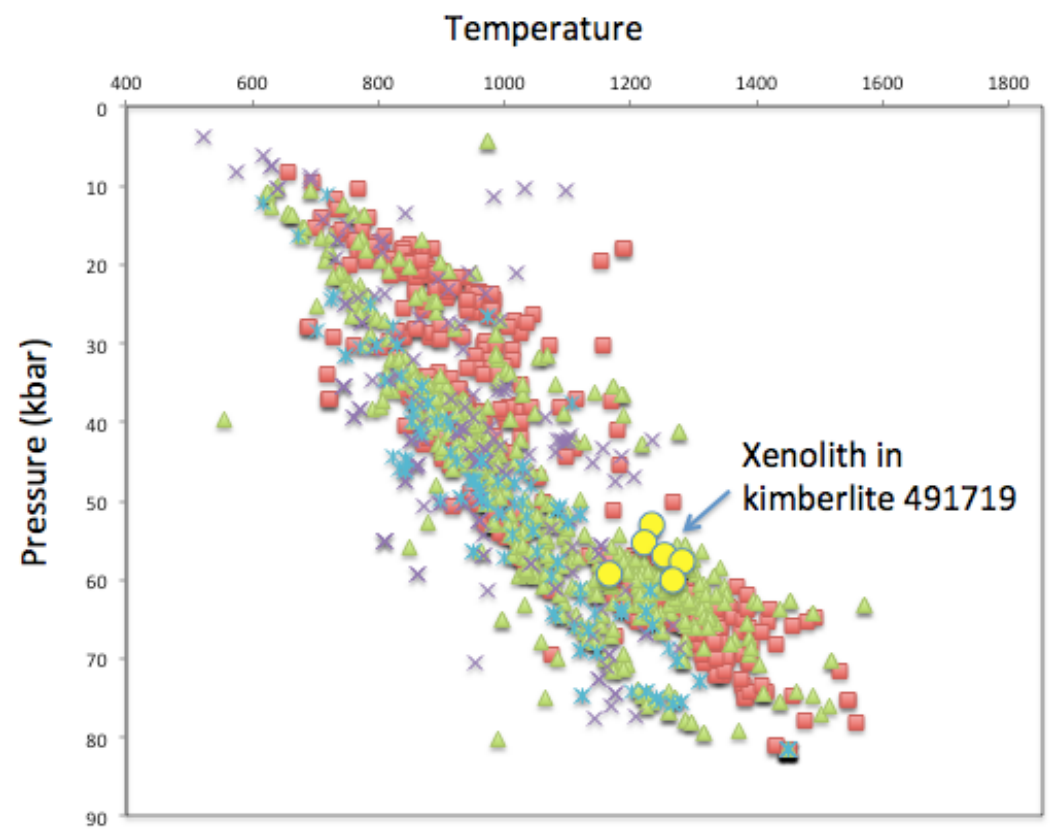

Figure 2: Pressure temperature diagram showing calculated equilibrium conditions for minerals in the kimberlite sample 491719 and in xenoliths from other locations (data from I. Ashchepkov, unpublished.)

\section{Marginal zones}

In another kimberlite from the same area, thin marginal zones in which the Ni content plummets as Fo content remains nearly constant surround microxenoliths of dunite and isolated olivine grains. These olivine margins are believed to have crystallized directly from the kimberlite melt. If a high $\mathrm{Ni}$ partition coefficient is adopted $\left(\mathrm{D}_{\mathrm{Ni}}>20\right)$, crystallization of olivine alone, without orhtopyroxene dissolution, can explain the trends (Cordier et al., 2015).

\section{Conclusion}

From these results we propose that almost all olivine in kimberlites, with the exception of the marginal zones, are fragments of dunite that was produced during interaction between mantle peridotite and $\mathrm{CO} 2$-rich fluid and that this interaction occurred immediately before or during deformation, near the base of the lithosphere.

\section{References}

Cordier, C., Sauziat, L., Arndt. N.T., Boullier, A.-M., Batanova, V., Barou, F. (2015) Metasomatism of the lithospheric mantle immediately precedes kimberlite eruption: new evidence from olivine composition and microstructures. Journal of Petrology 56, 1775-1796 